Lázaro, Lara. La Cop21 y el Acuerdo de París: una clase magistral en diplomacia en busca de mayor ambición.

\title{
LA COP21 Y EL ACUERDO DE PARÍS: UNA CLASE MAGISTRAL EN DIPLOMACIA EN BUSCA DE MAYOR AMBICIÓN
}

\section{COP21 AND THE PARIS AGREEMENT: A DIPLOMACY MASTERCLASS IN SEARCH OF GREATER CLIMATE AMBITION. ${ }^{1}$}

\author{
LARA LÁZARO \\ Real Instituto Elcano \\ Colegio Universitario Cardenal Cisneros \\ llazaro@rielcano.es
}

Fecha de recepción: mayo 2016

Fecha de aceptación: noviembre 2016

\begin{abstract}
RESUMEN
Muchos de los elementos clave que resultaron en el Acuerdo de Copenhague han evolucionado en los últimos seis años. Una mayor evidencia científica, un mayor desarrollo en el análisis económico relativo a las consecuencias del cambio climático, los avances tecnológicos, el desarrollo del sector energético renovable y las transformaciones en la gobernanza climática han posibilitado la adopción del Acuerdo de Paris. El presente artículo analiza algunos de estos factores, los resultados de la COP21 y los retos pendientes. El artículo concluye que el éxito diplomático que culminó en el Acuerdo de París dota al mundo de un nuevo marco global en la gobernanza climática que contiene elementos valiosos en la lucha contra el cambio climático. Sin embargo, los compromisos climáticos actuales llevarán a sobrepasar en aproximadamente un grado el objetivo de limitar el aumento medio de la temperatura global a $2^{\circ} \mathrm{C}$. Es necesario aumentar el grado de ambición. Nuestros esfuerzos de implementación tienen que comenzar sin dilación si hemos de evitar las peores consecuencias del cambio climático. La tarea pendiente es hercúlea ya que resolver el problema climático requiere la profunda transformación de los sistemas productivos y de consumo.
\end{abstract}

PALABRAS CLAVE: Cambio climático, COP21, INDCs y descarbonización

\begin{abstract}
Many key elements that led to the Copenhagen Accord have evolved in the past six years. Increased scientific evidence, updated economic analysis on the consequences of climate change, technological advances, developments in the renewable energy sector and transformations in climate governance have created a narrow window of opportunity through which the Paris Agreement emerged. Some of
\end{abstract}

\footnotetext{
${ }^{1}$ Note to the editor. The current article is an updated version of 'COP21 and the Paris Agreement: a diplomacy masterclass in search of greater ambition’ published by Elcano Royal Institute.
} 
Lázaro, Lara. La Cop21 y el Acuerdo de París: una clase magistral en diplomacia en busca de mayor ambición.

these key changes, the results of COP21 and the challenges ahead are critically analysed. The analysis concludes that the diplomatic success that culminated in the adoption of the Paris Agreement provides the world with a new global climate governance framework that contains valuable elements in the fight against climate change. However, current mitigation commitments will overshoot the $2^{\circ} \mathrm{C}$ limit by around one degree. Therefore more needs to be done and work has to start in earnest now if we are to avoid the worst consequences of a changing climate. The task at hand is herculean as solving the climate problem requires profoundly transforming productive systems and consumption patterns.

KEY WORDS: Climate change, COP21, INDCs and decarbonisation

JEL: Q54, F53 
Lázaro, Lara. La Cop21 y el Acuerdo de París: una clase magistral en diplomacia en busca de mayor ambición.

\section{FROM COPENHAGEN TO PARIS}

\subsection{Science, economics, law and energy}

The road from Copenhagen to Paris has been paved by developments in science, economics, law, energy and climate governance. The science is more robust in 2015 than it was in 2009. In fact, the publication of the Fifth Assessment Report (AR5) by the Intergovernmental Panel on Climate Change (IPCC) in 2013-2014 stated that climate change is unequivocal, it is already impacting socioeconomic and natural systems alike, and human influence on this process is clear (IPCC, 2014). There is an overwhelming agreement among scientists ( $97 \%$ agree) that climate change is happening and that its anthropogenic component is significant. The scientific debate regarding the existence of climate change and its anthropogenic origin has finally been laid to rest ${ }^{2}$.

Climate change economists agree that climate models underestimate the consequences of climate change. They also agree that action in earnest is called for (Stern, 2007) as climate change is already affecting our economies, or will do so in the medium and long-term (Howard and Sylvan, 2015). In fact, analysis by Dell et al. (2011) on less developed countries, as well as Burke et al. (2015), confirm the relationship between economic growth and temperature increases. The latter conclude that economic productivity reaches its peak at an average temperature of $13^{\circ} \mathrm{C}$ with sharp declines in productivity at higher average temperatures. By the end of the century global GDP per capita could be $23 \%$ lower in high greenhouse gas (GHG) emission scenarios compared to those where there is no climate change (Burke et al., 2015), a powerful reason to limit our emissions. Limitation in economic modelling and forecasting (Aghion et al. 2014; Stern, 2013; Zenghelis, 2016, pers. Comm.;) should however caution against relying on any particular figure.

In a recently conducted survey by the World Economic Forum among 750 of its members, extreme weather events, natural catastrophes and failure to mitigate and adapt to climate change were ranked among the most likely global risks, with failure to take climate action also being the global risk with highest impact within the next 10 years (WEF, 2016). It is hence not surprising that mainstreaming climate risk analysis in investment portfolios is beginning to occur. According to BlackRock (2015) asset owners are starting to worry about stranded assets and companies that are most vulnerable to physical or regulatory climate risks could trade at a discount in the future. The inclusion of climate risk analysis in investment portfolios is expected to negatively impact high cost oil companies and oil exporting countries while positively impacting parts of the renewable energy industry, companies in the energy efficiency business and the clean technology sector. The arguments for divesting are mounting.

Beyond the concern about stranded assets, the impact of climate change on asset value is beginning to concern financial regulators and investors. Recent work by Dietz et al. (2016) on climate value at risk ( $\mathrm{VaR})$ analyses the loss of asset value due to the destruction, or acceleration in the depreciation, of capital assets and from the

\footnotetext{
${ }^{2}$ The political understanding and agreement regarding this matter is however asymmetric with still some politicians in the US for instance questioning the science behind climate change and blocking decisive action on this issue (Bodansky and Day O'Connor, forthcoming).
} 
Lázaro, Lara. La Cop21 y el Acuerdo de París: una clase magistral en diplomacia en busca de mayor ambición.

reduction in output as a result of climate change. The authors of the study argue that to the extent that financial assets are backed by economic activities, reductions in growth can lead to losses in the value of financial assets. Assuming a value of global non-bank financial assets of US\$ 143.3 trillion in 2013, the study finds that the mean climate value at risk (climate VaR) is $1.8 \%$ or US $\$ 2.5$ trillion under a $2.5^{\circ} \mathrm{C}$ warming scenario to 2100 (the $99^{\text {th }}$ percentile however would entail a climate VaR of $16.9 \%$ or US $\$ 24.2$ trillion). Under a $2^{\circ} \mathrm{C}$ warming scenario the mean climate VaR is $1.2 \%$ or US\$1.7 trillion (the $99^{\text {th }}$ percentile would however imply a climate VaR of $9.2 \%$ or US $\$ 13.3$ trillion). The present value of financial assets is set to be larger under a $2^{\circ} \mathrm{C}$ warmer scenario and hence risk neutral and risk averse investors should call for mitigation according to the authors.

In addition to the concerns regarding stranded assets and the climate VaR, lawyers are exploring the possibility of future law suits against fund and pension managers that fail to take into account material risks such as climate change that could reduce the value of investments by $5 \%$ or more (Covington, Thorton and Hepburn, 2016).

The cost of renewable energy has dropped dramatically since Copenhagen. Costs for solar photovoltaic modules fell by $65 \%-70 \%$ between 2009 and 2013, photovoltaic (PV) prices have dropped $80 \%$ since 2008 and onshore wind electricity costs have dropped by $18 \%$ (IRENA, 2014). In the coming years the cost of renewable energy is expected to be further reduced and solar photovoltaic is expected to reach grid parity in $80 \%$ of countries in the next two years (University of Cambridge and PwC, 2015). Given that energy represents a significant share (35\%) of global emissions (IPCC, 2014), any cost reduction in low carbon energy sources is good news for the energy transition.

\subsection{Climate change governance ahead of COP21: from the French Presidency to the Pope}

The French Presidency of COP21 worked throughout 2015 to prepare the climate conference in Paris. The COP President, Laurent Fabius, as well as his team, were praised throughout the meeting for their ability to listen, ensure transparency (The Climate Group, 2015) and broker consensus on the main sticking points in the negotiating texts. One of the innovative moves by the French was to invite Heads of State and Government to intervene at the beginning rather than at the end of the COP, as was the case in Copenhagen. This early engagement showcased political will and arguably helped push technical work forward from the outset.

In stark contrast to COP15, expectations as regards the outcome of the Paris Conference were lower than expectations regarding the outcome of the Copenhagen Conference. French diplomacy, think tanks and academics alike had warned the world that COP21 results would not solve the climate change problem. Paris was not thought of as the COP to end all COPs, as was perhaps Copenhagen for some outside observers. The fact that an agreement to replace the Kyoto Protocol was not reached during COP15 and the realisation that solving the climate problem means totally transforming productive systems and consumption patterns were powerful reasons to purposefully lower expectations as regards the Paris outcome. 
Lázaro, Lara. La Cop21 y el Acuerdo de París: una clase magistral en diplomacia en busca de mayor ambición.

Following a bottom-up approach to raising ambition, all countries, developed and developing, were asked in December 2013 to submit their Intended Nationally Determined Contributions (INDCs) ${ }^{3}$ well in advance of COP21, according to their common but differentiated responsibilities and respective capabilities (CBDR-RC) in the light of national circumstances. This is a substantial change from the Kyoto Protocol that was based on developed countries ${ }^{4}$ being the only ones with emission reduction targets. There has hence been a transition from blame to collective will to act according to national possibilities and priorities. The result was that by the $1^{\text {st }}$ of October 2015 some 119 INDCs from 147 Parties, amounting to $86 \%$ of global emissions in 2010, had been submitted, a first in the history of climate negotiations (UNFCCC, 2015a) $)^{5}$. These figures are indeed impressive as they include almost all Parties and all major GHG emitters.

Key emitters were on board. China and the US had jointly announced in November 2014 their intention to work together to ensure the adoption of an agreement in Paris. In its INDC the US announced it would reduce its emission in 2025 by $26 \%-28 \%$ below its 2005 level, emphasising that the target is in line with an $80 \%$ reduction of GHG emissions by $2050^{6}$.

China's INDC claimed its intention to both reach its emissions peak and increase the share of non-fossil fuel energy sources in its energy mix to $20 \%$ by 2030 . In addition, China's $\mathrm{CO}_{2}$ intensity per unit of GDP is to be reduced by $60 \%-65 \%$ compared to 2005 levels. China also committed to increase forest stock volume by 4.5 billion cubic meters compared to 2005 levels ${ }^{7}$.

Europe's contribution was announced ahead of those of the US and China at the European Council in October 2014. The European INDC included an economy-wide GHG reduction target of no less than $40 \%$ by 2030 compared to 1990 . This target is to be jointly fulfilled, with no use of international market-based mechanisms. Allocation of the targets among member countries is yet to be finalised.

However, the commitments described above, contained in the US, China and European INDCs, are rated as 'medium' according to Climate Action Tracker ${ }^{8}$. This means that if all governments' efforts were in this range, global average warming would likely exceed $2^{\circ} \mathrm{C}$. This is also the case of other major emitters such as Brazil and India. INDCs submitted by Japan, Russia or South Africa, among others, are rated as insufficient, meaning that if all governments put made similar efforts to those of these countries, global average warming would likely be in the range of $3^{\circ} \mathrm{C}$ to $4^{\circ} \mathrm{C}$. Only Bhutan, Costa Rica, Ethiopia, Gambia and Morocco (the latter being the future COP22 presidency) have submitted intended contributions in line with the goal of limiting mean global temperature increases to $2^{\circ} \mathrm{C}$.

\footnotetext{
${ }^{3}$ Intended Nationally Determined Contributions (INDCs) are countries post 2020 climate commitments.

${ }^{4}$ Developed countries have historically emitted more GHG (Friedrich and Damassa, 2014).

${ }^{5}$ The submission of INDCs continued throughout the COP and in the months that followed.

${ }^{6}$ http://ow.ly/uV7n3001dr9

${ }^{7}$ http://ow.ly/N2983001dsx Additionally, the joint statement by China and the US in September 2015 confirmed China's intention of launching a nation-wide emissions trading scheme by 2017 that would cover the power sector as well as the main industrial sectors. A 'green dispatch' will also be implemented to promote low-carbon energy sources in the electricity mix.

${ }^{8} \mathrm{http}: / /$ climateactiontracker.org/indes.html
} 
Lázaro, Lara. La Cop21 y el Acuerdo de París: una clase magistral en diplomacia en busca de mayor ambición.

Therefore, neither INDCs submitted before or during COP21 are enough to provide the world with a reasonable probability of limiting the average global temperatures to $2^{\circ} \mathrm{C}$ above pre-industrial levels. In fact, the median increase in global average temperatures is likely to be $2.7^{\circ} \mathrm{C}$ in 2100 compared to pre-industrial levels, provided all pledges included in the INDCs are fully implemented (Climate Action Tracker, $2015 a, b)$. This reality check reinforces the need for continued negotiations and increased ambition over time.

In addition to national commitments unprecedented action at subnational, city and firm level is occurring. The traditional top-down approach to climate regime building is being progressively transformed. Initiatives from business, cities, regions and civil society have been channelled, inter alia, through the Lima-Paris Action Agenda (LPAA). The LPAA resulted in approximately 11,000 concrete actions, engagement by over 2,000 cities, more than 2,000 companies $^{9}$ (with a market value equivalent to the GDP of China, France and Germany combined) as well as more than 200 civil society organisations.

Finally, in 2009 the Interfaith Declaration on Climate Change (García Acuña, 2010) was presented during COP15 to Yvo de Boer ${ }^{10}$. In the document many of the world's religious faiths called for decisive action to fight climate change and stated that 'climate change is not merely an economic or technical problem, but rather at its core is a moral, spiritual and cultural one'11. Six years later, the publishing of Pope Francis' Encyclical Letter 'Laudato Si' on the care of our common home has made headline news and has contributed to the outcome in Paris. In that Letter Pope Francis calls for 'substituting fossil fuels and developing sources of renewable energy' (Bergoglio, 2015: 21).

\section{THE PARIS AGREEMENT. MAIN ELEMENTS AND PRELIMINARY ASSESSMENT}

After over 20 years of climate negotiations the Paris Agreement adopted in 2015 could be remembered for providing humanity with the framework for decisive climate action, if current INDCs are fully implemented and ambition is regularly ramped-up. In order for increased ambition to materialise an orderly and asymmetric transition to a low carbon economy is needed. A monumental task considering that this transmutation would have to occur in almost 200 countries at various stages of development and facing a wide variety of socio-economic and political situations. The joy of diplomatic success must not lead to complacency. We have to act now and continue to do so until low carbon economies become the norm. Success will be measured against the $2^{\circ} \mathrm{C}\left(1.5^{\circ} \mathrm{C}\right)$ benchmark and that will require nothing short of a post-industrial green revolution. The key elements in the Paris Agreement are summarised in table 1 below:

\footnotetext{
${ }^{9} \mathrm{http}: / /$ newsroom.unfccc.int/lpaa/lpaa/massive-mobilization-by-non-state-stakeholders-summarized-at-cop21/

${ }^{10}$ Yvo de Boer was the Executive Secretary of the UNFCCC from 2006 to 2010.

${ }^{11} \mathrm{http}: / / \mathrm{www}$. interfaithdeclaration.org/download/idcc_english.pdf
} 
Lázaro, Lara. La Cop21 y el Acuerdo de París: una clase magistral en diplomacia en busca de mayor ambición.

Table 1. Some key elements of the Paris Agreement

\begin{tabular}{|c|c|c|}
\hline Area & Status / Goal & Comment \\
\hline $\begin{array}{l}\text { Nature of the } \\
\text { Paris } \\
\text { Agreement }\end{array}$ & $\begin{array}{l}\text { Legally binding international } \\
\text { agreement under the Vienna } \\
\text { Convention. }\end{array}$ & $\begin{array}{l}\text { No legally binding targets are included, as this } \\
\text { would have prevented the US from adopting the } \\
\text { agreement. All countries are however obliged to } \\
\text { have INDCs but there are no sanctions for failing } \\
\text { to meet goals. }\end{array}$ \\
\hline Differentiation & $\begin{array}{l}\text { Parties will act according to } \\
\text { their common but differentiated } \\
\text { responsibilities and respective } \\
\text { capabilities (CBDR-RC), in the } \\
\text { light of different national } \\
\text { circumstances. }\end{array}$ & $\begin{array}{l}\text { The CBDR-RC principle was enshrined in the } \\
\text { United Nations Framework Convention on Climate } \\
\text { Change (UNFCCC) to account for historical } \\
\text { responsibility and asymmetric capacity to act. } \\
\text { Developed countries should continue taking the } \\
\text { lead via economy-wide absolute emission } \\
\text { reduction commitments. }\end{array}$ \\
\hline \multirow{5}{*}{$\begin{array}{l}\text { Mitigation \& } \\
\text { ambition }\end{array}$} & $\begin{array}{l}\text { Limit temperature increases to } \\
\text { well below } 2^{\circ} \mathrm{C} \text {, aspiring to } \\
1.5^{\circ} \mathrm{C} \text {. }\end{array}$ & $\begin{array}{l}\text { The } 1.5^{\circ} \mathrm{C} \text { goal has been a historic demand by } \\
\text { Small Island Developing States, among others, } \\
\text { that are threatened by sea-level rise. }\end{array}$ \\
\hline & $\begin{array}{l}\text { Emissions will peak as soon as } \\
\text { possible and decline thereafter }\end{array}$ & $\begin{array}{l}\text { Developing country emissions will take longer to } \\
\text { reach their peak in emissions. }\end{array}$ \\
\hline & $\begin{array}{l}\text { Balance between GHG } \\
\text { emissions and removals by } \\
\text { sinks should occur in the } \\
\text { second half of the century. This } \\
\text { is a legally binding element of } \\
\text { the agreement. }\end{array}$ & $\begin{array}{l}\text { A quantified emission reduction target by } 2050 \\
\text { failed to make it into the agreement. } \\
\text { The decision on balance of emissions opens the } \\
\text { door to the use of Carbon Capture and Storage } \\
\text { (CCS) but technical, environmental and economic } \\
\text { issues are still to be resolved. }\end{array}$ \\
\hline & $\begin{array}{l}\text { Parties will submit their } \\
\text { nationally determined } \\
\text { contribution every five years }\end{array}$ & $\begin{array}{l}\text { Ambition has to increase in each INDC } \\
\text { submission. Ratcheting up of ambition can occur } \\
\text { at any time. } \\
\text { Submissions should be made } 9 \text { to } 12 \text { months in } \\
\text { advance of the next COP to allow for adequate } \\
\text { analysis of contributions. }\end{array}$ \\
\hline & $\begin{array}{l}\text { Parties should enhance sinks, } \\
\text { including forests. }\end{array}$ & $\begin{array}{l}\text { The inclusion of article } 5 \text { on forests in the } \\
\text { agreement has been a welcomed development as } \\
\text { almost a fourth of global emissions come from } \\
\text { agriculture, forestry and other land use (AFOLU) }\end{array}$ \\
\hline Progress & $\begin{array}{l}\text { A global stocktake will take } \\
\text { place every five years, starting } \\
\text { in } 2023 \text {. } \\
\text { A facilitative dialogue will occur } \\
\text { in } 2018 \text { to analyse progress } \\
\text { towards the long-term goal. }\end{array}$ & $\begin{array}{l}\text { The global stocktaking will help Parties 'update } \\
\text { and enhance' (i.e. ratchet up) their INDCs. }\end{array}$ \\
\hline Finance & $\begin{array}{l}\text { US } \$ 100 \text { billion per annum from } \\
2020 \text { to } 2025 \text {. A new goal will } \\
\text { be set prior to } 2025 \text {, with a } \\
\text { floor of US } \$ 100 \text { billion. }\end{array}$ & $\begin{array}{l}\text { Developed countries must provide finance. } \\
\text { Developing countries can provide finance. } \\
\text { Less developed countries demanded intermediate } \\
\text { finance goals that were not included in the final } \\
\text { version of the Paris Agreement. } \\
\text { Work on different modalities for accounting for } \\
\text { financial resources will be presented at COP24 in } \\
2018 \text {. }\end{array}$ \\
\hline ITMOs & $\begin{array}{l}\text { Cooperation among countries } \\
\text { is fostered by the creation of } \\
\text { Internationally Transferred } \\
\text { Mitigation Outcomes (ITMOs). }\end{array}$ & $\begin{array}{l}\text { The ITMOs are voluntary instruments that have to } \\
\text { be authorised by Parties. Double counting is to be } \\
\text { avoided and a net mitigation impact is to be } \\
\text { pursued. }\end{array}$ \\
\hline Adaptation & $\begin{array}{l}\text { Future work entails developing } \\
\text { methods to recognise } \\
\text { adaptation efforts by } \\
\text { developing countries. }\end{array}$ & $\begin{array}{l}\text { Significant advances in this area were achieved } \\
\text { after the first week of negotiations. The Green } \\
\text { Climate Fund will disburse funds for developing } \\
\text { countries and least developed countries to } \\
\text { produce their adaptation plans. }\end{array}$ \\
\hline
\end{tabular}


Lázaro, Lara. La Cop21 y el Acuerdo de París: una clase magistral en diplomacia en busca de mayor ambición.

\begin{tabular}{|l|l|l|}
\hline $\begin{array}{l}\text { Loss and } \\
\text { damage }\end{array}$ & $\begin{array}{l}\text { The work of the Warsaw } \\
\text { International Mechanism on } \\
\text { Loss and Damage will } \\
\text { continue. }\end{array}$ & $\begin{array}{l}\text { No liability can be claimed. Developed countries } \\
\text { can assist developing countries by providing } \\
\text { technical assistance, among others. }\end{array}$ \\
\hline Transparency & $\begin{array}{l}\text { Establishes a Capacity-building } \\
\text { Initiative for Transparency. }\end{array}$ & $\begin{array}{l}\text { Parties will be subject to a common transparency } \\
\text { framework, although agreeing on third party } \\
\text { oversight (a US demand) was opposed by India } \\
\text { and China. }\end{array}$ \\
\hline $\begin{array}{l}\text { Capacity } \\
\text { building }\end{array}$ & $\begin{array}{l}\text { The Paris Committee on } \\
\text { Capacity-building was was when } \\
\text { established with a work plan } \\
\text { for 2016-2020. }\end{array}$ & $\begin{array}{l}\text { Significant advances in this area were achieved } \\
\text { after the first week of negotiations. }\end{array}$ \\
\hline $\begin{array}{l}\text { Technology } \\
\text { development } \\
\text { and transfer }\end{array}$ & $\begin{array}{l}\text { A technology framework will } \\
\text { analyse technology needs, } \\
\text { implementation and action } \\
\text { plans, inter alia. The goal is to } \\
\text { accelerate innovation. }\end{array}$ & $\begin{array}{l}\text { Significant advances in this area were achieved } \\
\text { after the first week of negotiations. Financial } \\
\text { support will be provided for developing countries, } \\
\text { especially for technologies in early stages of } \\
\text { development. }\end{array}$ \\
\hline
\end{tabular}

Sources: Draft decision -/CP.21. The Paris Agreement; Day et al. (2015) and Ulargui (pers. comm).

\subsection{A preliminary assessment of the Paris Agreement}

At the time of writing 162 INDCs corresponding to 189 Parties, which account for over $98 \%$ of global emissions, have been submitted ${ }^{12}$. This almost universal participation has led some institutions to state that the Paris Agreement has been a success. Furthermore, 175 Parties signed the Paris Agreement at the UN Headquarters in New York on April the $22^{\text {nd }}$, breaking the record number of signatures on the first day for any multilateral agreement. The agreement was also ratified by fifteen Parties, mainly Small Island Developing States (UNFCCC, 2016) ${ }^{13}$. This almost universal effort is a sign of the political capital invested in the success of COP21. The political momentum, aided by the driving forces that enabled the adoption of the Paris Agreement, seems strong.

The above goals and efforts could provide the framework for an 'ambition spiral' to be unleashed. The references to $2^{\circ} \mathrm{C}$ (and $1.5^{\circ} \mathrm{C}$ ) plus the goal of net zero emissions by the second half of the century provide us with a collective way forward as it anchors expectations for governments and businesses alike on the direction of travel towards decarbonisation. The hybrid architecture of the agreement, with national commitments (that are development compatible) but with an international transparency and accountability framework, have been enshrined into a durable agreement with periodic reviews that are set to increase ambition over time.

Despite the positive elements detailed above, the agreement opted for universal participation and hence, understandably, fell short of the required ambition level. During the negotiation process various issues of paramount importance were left out of the agreement. These include: a $\mathrm{CO}_{2}$ price, a quantified emission reduction target

\footnotetext{
12 http://cait.wri.org/indc/

${ }^{13}$ The countries that ratified the Paris Agreement on April 22 $2^{\text {nd }}$ were: Marshall Islands, Nauru, Palau, Somalia, State of Palestine, Barbados, Belize, Fiji, Grenada, Saint Kitts \& Nevis, Samoa, Tuvalu, Maldives, Saint Lucia, and Mauritius. See: http://newsroom.unfccc.int/paris-agreement/closing-paris-agreement-signingpress-release/. Note that the Paris Agreement will not enter into force until 55 Parties or more that represent at least $55 \%$ of global emissions have 'deposited their instruments of ratification, acceptance, approval or accession' (UNFCCC, 2015b: 31) to the Paris Agreement.
} 
Lázaro, Lara. La Cop21 y el Acuerdo de París: una clase magistral en diplomacia en busca de mayor ambición.

by 2050 , sectorial references regarding energy, the built environment and the role of cities. The international transport sector and bunkers (aviation and shipping), whose emissions could represent $40 \%$ by the middle of the century (European Parliament, 2015), have been left out. There are furthermore other issues that have not been adequately specified in the Paris Agreement such as the sources of climate finance, accounting guidelines, how climate finance would be allocated and managed. Finally, despite the fact that the term 'climate justice' is mentioned in the Paris Agreement some authors have argued that equity has been effectively side-lined. This is due to the fact that historical responsibility is not tackled and developing countries are required to present their INDCs and to engage in increasingly ambitious climate action (Clemençon, 2016).

\section{THE CHALLENGES AHEAD: THE CLIMATE TROIKA.}

The discussion as regards ambition in the past few years has focused on INDCs. Looking ahead, implementing their commitments and ramping up ambition, subject to the availability of adequate finance, technology and skills, are a must if we are to avert the worst consequences of climate change.

The climate troika (implementation, increased ambition and means) are analysed by Averchenkova and Bassi (2016) as the pillars of future climate action. The authors argue that given the lack of penalties in the Paris Agreement, in contrast with the Kyoto Protocol, and given the insufficient ambition in current commitments (UNEP, 2015; Boyd et al, 2015; Climate Action Tracker, 2015) the credibility ${ }^{14}$ regarding the implementation of current climate commitments could be expected to help build trust amongst Parties, encourage transparent reporting and attract investment. Achieving success in the early implementation of INDCs could in turn increase the countries willingness to increase future ambition, setting in motion a virtuous circle of climate action. In their analysis, Averchenkova and Bassi conclude that improvements in terms of credibility for G20 countries could be achieved, inter alia, by increasing transparency, fostering inclusive and effective decision-making processes and avoiding policy reversals.

Moving forward both developed and developing countries are faced with the task of transforming their socioeconomic systems, their energy and land use sectors in order to limit the worst consequences of climate change. Table 2 below provides a summary of the key elements that can help implement NDCs ${ }^{15}$.

Table 2. Drivers of NDC implementation

\begin{tabular}{|l|l|}
\hline Driver & Comment \\
\hline $\begin{array}{l}\text { Framework } \\
\text { legislation }\end{array}$ & $\begin{array}{l}\text { Examples include, inter alia, the UK's Climate Change Act (2008) or the French } \\
\text { Energy Transition for Green Growth law (2015) }\end{array}$ \\
\hline $\begin{array}{l}\text { Economic } \\
\text { instruments and } \\
\text { valuation }\end{array}$ & $\begin{array}{l}\text { Carbon pricing through taxes or emission trading systems (that can achieve } \\
\text { static and dynamic efficiency) should be implemented. } \\
\text { Country-wide and sectorial cost-benefit analysis of climate action and inaction } \\
\text { should be promoted and their results integrated in policy assessments. }\end{array}$ \\
\hline & \\
\hline
\end{tabular}

\footnotetext{
${ }^{14}$ Credibility according to Averchenkova and Bassi (2016) can be defined as the likelihood of implementation of climate pledges.

${ }^{15}$ INDCs are to be converted into Nationally Determined Contributions (NDCs).
} 
Lázaro, Lara. La Cop21 y el Acuerdo de París: una clase magistral en diplomacia en busca de mayor ambición.

\begin{tabular}{|l|l|}
\hline $\begin{array}{l}\text { Operationalization } \\
\text { and prioritisation }\end{array}$ & $\begin{array}{l}\text { NDCs have to be translated into concrete plans and actions for the different } \\
\text { economic sectors. }\end{array}$ \\
\hline $\begin{array}{l}\text { Environmental } \\
\text { Policy Integration }\end{array}$ & $\begin{array}{l}\text { Climate awareness should be raised across ministries, especially economics } \\
\text { and finance ministries. Instruments such as green budgeting should be } \\
\text { encouraged. The ultimate goal is to elaborate low emission development } \\
\text { strategies (LEDS). }\end{array}$ \\
\hline $\begin{array}{l}\text { Institutional } \\
\text { framework } \\
\text { attribution }\end{array} \quad \begin{array}{l}\text { Independent consultative bodies should be available and climate leaders } \\
\text { identified. Responsibilities as regards climate policies should be clearly } \\
\text { assigned among institutions. } \\
\text { An appropriate governance framework inclusive of national and sub-national } \\
\text { governments, cities, business and Civil Society Organisations (CSOs) should } \\
\text { be available. }\end{array}$ \\
\hline Appropriation & $\begin{array}{l}\text { National stakeholders should be involved in the co-creation of NDCs while } \\
\text { ensuring transparency and avoiding double counting. Political buy-in should be } \\
\text { secured in the long run. Better communication on climate change issues should } \\
\text { be pursued. Messages should portray the proximate and known consequences } \\
\text { of climate change as these could increase citizen awareness and will to act. }\end{array}$ \\
\hline $\begin{array}{l}\text { Resources and } \\
\text { knowledge }\end{array}$ & $\begin{array}{l}\text { The key needs in terms of resources and information include: stable and } \\
\text { predictable finance, access to clean technologies, capacity building, monitoring, } \\
\text { reporting and verification (MRV) knowledge and capabilities, information on } \\
\text { transparency, clarity regarding compliance rules and procedures. }\end{array}$ \\
\hline
\end{tabular}

Sources: Averchenkova and Bassi (2016); Comstock (2016); Escribano and Lázaro (2016)

As a necessary companion to implementation, rules, modalities, guidelines and procedures have to be established (UNDP, 2016). This work will start in Bonn by mid May 2016. Further developments are needed as regards the Internationally Traded Mitigation Outcomes (ITMOs), the new Sustainable Development Mechanism $(\mathrm{SDM})^{16}$, the transparency framework, global stocktake and ratcheting up process (Bodansky and O'Connor, forthcoming). Parties should on the other hand start preparing for the implementation of the NDCs even before the entire set of rules and modalities are fully fleshed out by the UNFCCC. They should also start working on their low emission development strategies and they should continue supporting less developed countries through finance, technology transfers and capacity building. The road ahead looks significantly more complex and winding than the road already travelled.

Concerning ambition a significant increase in mitigation commitments by the main emitters is needed (Bailey and Tomlinson, 2016). In order to limit global mean temperature increases to below $2^{\circ} \mathrm{C}$ a recent MIT study reiterates the known figures of the need to reduce GHG emissions by developed countries by $80 \%$ by mid century compared to 2005. Developing countries' emissions should peak ahead of 2030 and reduce emissions in absolute terms thereafter. More specifically, this would mean that the EU reduces its emission by $47 \%$ below 1990 levels by 2030 , the US and other developed countries reduce their emissions by $45 \%$ below 2005 levels by 2030 and China's emissions peak by 2025, with other developing country emissions peaking shortly after (Sterman et al., 2015). The EU's recent communication on the Paris Agreement (EC, 2016) and the US political context do not seem encouraging in this respect. China's changing economic structure (that is moving away from carbon intensive sectors) could imply it is among the few large emitters to comply with the

\footnotetext{
${ }^{16}$ The SDM would encompass offsets from both developed and developing countries (as the Clean Development Mechanism- CDM- and the Joint Implementation -JI- did under the Kyoto Protocol) at a project, program and policy level.
} 
Lázaro, Lara. La Cop21 y el Acuerdo de París: una clase magistral en diplomacia en busca de mayor ambición.

early peaking of GHG emissions needed to limit global mean temperature increases to $2^{\circ} \mathrm{C}$ (Green and Stern, 2016). If the EU and the US want to lead by example their ambition has to be increased soon.

\section{CONCLUSIONS}

Many things have changed since Copenhagen. Developments in science, energy, economics, law and governance have made Paris possible. The Paris Agreement could hence be seen as a lagged reflection of a transformation that has been in the make for some time. The Paris Agreement has to be commended however for catalysing action and anchoring expectations. Progress to date is insufficient but the direction of travel towards a low carbon future is clear.

The Paris Agreement has salvaged, for the time being, the multilateral climate process. The common narrative to pursue energy efficiency, energy security, development goals and more broadly sustainable development may have pushed climate commitments somewhat beyond the lowest common denominator. There is currently a broad approach to INDCs, which include commitments beyond GHG emission reductions, such as adaptation. There has also been a gradual blurring of the divide between developed and developing countries (Hermwille et al., 2015), by way of including all countries in the INDC scheme. Broadening of the INDC scope plus blurring of past country divisions may have facilitated, inter alia, the Paris Agreement.

A successful climate agreement in which there is broad participation, honouring of pledges and significant behavioural change by big emitters is what we should aspire to. This will mean institutionalising a new low carbon development paradigm (Bodansky and O'Connor, 2016). Some elements of this winning formula are in the Paris Agreement. Almost 200 countries adopted the Paris Agreement and current INDCs account for over $98 \%$ of world emissions. Paris brings a dynamic agreement that seeks to limit temperatures to well below $2^{\circ} \mathrm{C}$, demands net-zero emissions this century, ensures a transparency mechanism applicable to all and requires increased ambition, while accounting for differentiation and being supported by climate finance.

Missing elements in the agreement include a $\mathrm{CO}_{2}$ price, references to bunkers, greater specification as regards finance and implementation of the agreement. Current commitments, if fully implemented, will imply overshooting the $2^{\circ} \mathrm{C}$ goal by about one degree. This fact alone should motivate prompt, decisive and continued climate action by all stakeholders. The stakes could not be higher. 
Lázaro, Lara. La Cop21 y el Acuerdo de París: una clase magistral en diplomacia en busca de mayor ambición.

\section{REFERENCES}

Aghion, P. et al. (2014): Path dependence, innovation and the economics of climate change. November 2014. Centre for Climate Change Economics and Policy. Grantham Research Institute on Climate Change and the Environment. A contributing paper to: The New Climate Economy. Available on-line at: http://www.Ise.ac.uk/Granthamlnstitute/wpcontent/uploads/2014/11/Aghion_et_al_policy_paper_Nov20141.pdf

Averchenkova, A. and Bassi, S. (2016): Beyond the targets: assessing the political credibility of pledges for the Paris Agreement. Policy Brief. February 2016. Grantham Institute on Climate Change and the Environment. Available on-line at: http://eprints.Ise.ac.uk/65670/1/Averchenkova-and-Bassi-2016.pdf

Bailey, R. And Tomlinson, S. (2016): Post-Paris: Taking Forward the Global Climate Change Deal. Chatham House. Briefing. April 2016. Available on-line at: https://www.chathamhouse.org/sites/files/chathamhouse/publications/research/ 2016-04-21-post-paris-bailey-tomlinson.pdf

Bergoglio, Jorge (Papa Francisco) (2015): Encíclica Laudato Si. Romana Editorial.

BlackRock Investment Institute (2015): The Price of Climate Change. Global Warming Impacts on Portfolios. October 2015. Available at: https://www.blackrock.com/corporate/en-mx/literature/whitepaper/bii-pricingclimate-risk-international.pdf

Bodansky, D. and Day O'Connor, S. (forthcoming): 'The Paris Climate Change Agreement. A noe hope?'. American Journal of International Law. vol. 110. Available on-line

at: http://papers.ssrn.com/sol3/papers.cfm?abstract_id=2773895

Bodansky, D. (2010): 'The Copenhagen Climate Conference: a Post-Mortem. The American Journal of International Law'. Vol. 104, No. 2 (April 2010), pp. 230240. Available at: http://www.indiaenvironmentportal.org.in/files/SSRNid1553167.pdf

Boyd, R, Cranston Turner, J. and Ward, B., (2015): Tracking intended nationally determined contributions: what are the implications for greenhouse gas emissions in 2030? Policy paper. Grantham Research Institute on Climate Change and the Environment. Available at: http://www.Ise.ac.uk/Granthamlnstitute/publication/intended-nationallydetermined-contributions- what-are-the-implications-for-greenhouse-gasemissions-in-2030/

Burke, M. Hsiang, S. M. And Miguel, E. (2015): 'Global non-linear effect of temperature on economic production'. Nature 527, 235-239. doi:10.1038/nature15725.

Clémençon, R. (2016): 'The Two Sides of the Paris Climate Agreement: Dismal Failure or Historic Breakthrough?'. Journal of Environment \& Development. Vol. 25(1) 3-24.

Climate Action Tracker (2015a): 2.7 is not enough-we can get lower. Available online http://climateactiontracker.org/assets/publications/briefing_papers/CAT_Temp_ Update_COP21.pdf

Climate Action Tracker (2015b): Climate pledges will bring $2.7^{\circ} \mathrm{C}$ of warming, potential for more action. $8^{\text {th }}$ December 2015. Available on-line at: 
Lázaro, Lara. La Cop21 y el Acuerdo de París: una clase magistral en diplomacia en busca de mayor ambición.

http://climateactiontracker.org/news/253/Climate-pledges-will-bring-2.7C-ofwarming-potential-for-more-action.html

Comstock, M. (2016): Implementation Support Needs in Developing Countries. Webinar on Implementing NDCs: Next Steps \& Support Needs. UNDP. Available on-line at: https://www.youtube.com/watch?v=SDcEc3jVwis

Covington, H., Thorton, J. and Hepburn, C. (2016): 'Shareholders Must Vote for Climate-change Mitigation', Nature. 530: 156.

Day, T. et al., (2015): What the Paris Agreement means for global climate change mitigation. NewClimate Institute. Available on-line at: https://newclimate.org/2015/12/14/what-the-paris-agreement-means-for-globalclimate-change-mitigation/

Dell, M. Jones, B. F. And Olken, A. (2011): 'Temperature Shocks and Economic Growth: Evidence from the Last Half Century'. American Economic Journal: Macroeconomics 2012, 4 (3): 66-95 http://dx.doi.org/10.1257/mac.4.3.66

Dietz, S. et al. (2016): 'Climate value at risk' of global financial assets'. Nature Climate Change. http://dx.doi.org/10.1038/nclimate2972

EC (2016): The Road from Paris: assessing the implications of the Paris Agreement and accompanying the proposal for a Council decision on the signing, on behalf of the European Union, of the Paris agreement adopted under the United Nations Framework Convention on Climate Change. Available on-lineat: https://ec.europa.eu/transparency/regdoc/rep/1/2016/EN/1-2016-110-EN-F11.PDF

Escribano, G. and Lázaro, L. (2016): Energía y clima en 2016: en busca de una gobernanza policéntrica. ARI 28/2016 - 15/3/2016. Available on-line at: http://www.realinstitutoelcano.org/wps/portal/web/rielcano_es/contenido?WCM GLOBAL_CONTEXT=/elcano/elcano_es/especiales/especial+cambio+climatico /publicaciones+rie/ari+y+dt/ari28-2016-escribanofrances-lazarotouza-energiaclima-2016-busca-gobernanza-policentrica

European Parliament (2015): Emission reduction Targets for International Aviation and Shipping. Study for the ENVI Committee. Available on line at: http://www.europarl.europa.eu/RegData/etudes/STUD/2015/569964/IPOL_STU (2015)569964_EN.pdf

Friedrich, J. and Damassa, T. (2014): The History of Carbon Dioxide Emissions. May 21, 2014. World Resources Institute. Available on-line at: http://www.wri.org/blog/2014/05/history-carbon-dioxide-emissions

García Acuña, S. (2010): La Conferencia de Copenhague sobre el Clima y la Declaración Interreligiosa sobre el Cambio Climático: un acercamiento a la aportación de las religiones a la crisis atmosférica. Documento de Trabajo 18/2010. Real Instituto Elcano. Available at: http://www.realinstitutoelcano.org/wps/wcm/connect/b7e9ac0042d8e9109aaefb 5cb2335b49/DT18-

2010_declaracion_interreligiosa_cambio_climatico.pdf?MOD=AJPERES\&CAC HEID=b7e9ac0042d8e9109aaefb5cb2335b49

Green, F. And Stern, N. (2016): 'China's changing economy: implications for its carbon dioxide emissions'. Climate policy. DOI:10.1080/14693062.2016.1156515. 
Lázaro, Lara. La Cop21 y el Acuerdo de París: una clase magistral en diplomacia en busca de mayor ambición.

IPCC (2014): Climate Change 2014 Synthesis Report. Summary for Policymakers Chapter. Available on-line at: https://www.ipcc.ch/pdf/assessmentreport/ar5/syr/AR5_SYR_FINAL_SPM.pdf

IRENA (2014): REthinking Energy. Towards a New Power System. Available at: http://www.irena.org/rethinking/Rethinking_FullReport web.pdf

Hermwille, L., Obergassel, W., Ott H. E., and Beuermann,C. (2015): 'UNFCCC before and after Paris - what's necessary for an effective climate regime?', Climate Policy, DOI: 10.1080/14693062.2015.1115231

Howard, P. And Sylvan, D. (2015): Expert Consensus on the Economics of Climate Change. Institute for Policy Integrity. New York University School of Law. Available on-line

at: http://policyintegrity.org/files/publications/ExpertConsensusReport.pdf

http://blogs.ei.columbia.edu/2015/11/23/from-copenhagen-to-paris-low-expectations/ http://cait.wri.org/indc/

http://climateactiontracker.org/indcs.html

http://climateactiontracker.org/assets/publications/briefing_papers/CAT_COP21_Pari

s_Agreement_statement.pdf

http://climate.nasa.gov/scientific-consensus/

http://www.interfaithdeclaration.org/download/idcc_english.pdf

http://newsroom.unfccc.int/lpaa/lpaa/massive-mobilization-by-non-state-stakeholderssummarized-at-cop21/

http://unfccc.int/resource/docs/2013/cop19/eng/10a01.pdf\#page=3

http://w2.vatican.va/content/francesco/en/encyclicals/documents/papa-

francesco_20150524_enciclica-laudato-si.html

http://www4.unfccc.int/submissions/INDC/Published\%20Documents/China/1/China's \%20INDC\%20-\%20on\%2030\%20June\%202015.pdf

http://www4.unfccc.int/submissions/INDC/Published\%20Documents/United\%20State s\%20of\%20America/1/U.S.\%20Cover\%20Note\%20INDC\%20and\%20Accompa nying\%20Information.pdf

Sterman, J., Jones, A., Johnston, E. and Siegel, L. (2015): 'Climate Interactive Ratchet Success Pathway: Assumptions and Results', Climate Interactive. Available on-line at: https://www.climateinteractive.org/wpcontent/uploads/2015/12/Ratchet-Success-14-December-2015.pdf

Stern, N. (2013): 'The Structure of Economic Modelling of the Potential Impacts of Climate Change: Grafting Gross Underestimation of Risk onto Already Narrow Science Models'. Journal of Economic Literature 2013, 51(3), 838-859 http://dx.doi.org/10.1257/jel.51.3.838.

Stern, N. (2007): The Economics of Climate Change: the Stern Review. Cambridge: Cambridge University Press.

The Climate Group (2015): COP21: Damian Ryan asks if Paris is keeping on track. $3^{\text {rd }}$ of December 2015. Available on-line at: http://www.theclimategroup.org/what-we-do/news-and-blogs/cop21-damianryan-asks-if-paris-is-keeping-on-track/

UNDP (2016): Implementing NDCs: Next Steps and Support Needs. Webinar. 12th of April 2016. Available on-line at: https://www.youtube.com/watch?v=SDcEc3jVwis

UNEP (2015): The Emissions Gap Report 2015. United Nations Environment Programme (UNEP), Nairobi. 
Lázaro, Lara. La Cop21 y el Acuerdo de París: una clase magistral en diplomacia en busca de mayor ambición.

University of Cambridge and PwC (2015): Financing the Future of Energy. The opportunity for the Gulf's financial services sector. A report for the National Bank of Abu Dhabi. March 2015. Available on-line at: https://www.nbad.com/content/dam/NBAD/documents/Business/FOE_Full_Rep ort.pdf

UNFCCC (2015a): Synthesis report on the aggregate effect of the intended nationally determined contributions. Available on-line at: http://unfccc.int/resource/docs/2015/cop21/eng/07.pdf

UNFCCC (2015b): Adoption of the Paris Agreement. FCCC/CP/2015/L.9/Rev.1. Available on-line at: https://unfccc.int/resource/docs/2015/cop21/eng//09r01.pdf

UNFCCC (2016): Record Support for Advancing Paris Climate Agreement Entry into Force. Available on-line at: http://newsroom.unfccc.int/paris-agreement/closingparis-agreement-signing-press-release/

World Economic Forum (2016): Global Risks 2016. 11th edition. Available on-line at: http://www3.weforum.org/docs/Media/TheGlobalRisksReport2016.pdf 